\title{
Synthesis, Crystallization, and Dielectric Behaviour of Lead Bismuth Titanate Borosilicate Glasses with Addition of $1 \% \mathrm{La}_{2} \mathrm{O}_{3}$
}

\author{
C. R. Gautam, ${ }^{1}$ Abhishek Madheshiya, ${ }^{1}$ and R. K. Dwivedi ${ }^{2}$ \\ ${ }^{1}$ Advanced Glass and Glass Ceramic Research Laboratory, Department of Physics, University of Lucknow, Lucknow 226007, India \\ ${ }^{2}$ Department of Physics and Materials Science, Jaypee Institute of Information and Technology, Noida 201307, India
}

Correspondence should be addressed to C. R. Gautam; gautam_ceramic@yahoo.com

Received 9 May 2015; Accepted 16 June 2015

Academic Editor: Vladimir Privman

Copyright @ 2015 C. R. Gautam et al. This is an open access article distributed under the Creative Commons Attribution License, which permits unrestricted use, distribution, and reproduction in any medium, provided the original work is properly cited.

Lead bismuth titanate borosilicate glasses were prepared in the glass system $65\left[\left(\mathrm{~Pb}_{x} \mathrm{Bi}_{1-x}\right) \cdot \mathrm{TiO}_{3}\right]-34\left[2 \mathrm{SiO}_{2} \cdot \mathrm{B}_{2} \mathrm{O}_{3}\right]-1 \mathrm{La}_{2} \mathrm{O}_{3}(0.0 \leq$ $x \leq 1.0$ ) doped with one mole percent of $\mathrm{La}_{2} \mathrm{O}_{3}$ via conventional melt quench method. The amorphous nature of glass samples in this glass system is confirmed by using X-ray diffraction (XRD) study. Differential thermal analysis (DTA) has been employed to determine the glass transition temperature, $T_{g}$, as well as crystallization temperature, $T_{c}$. DTA measurements were recorded in temperature range from 30 to $1200^{\circ} \mathrm{C}$. The prepared glasses were crystallized by regulated controlled heat treatment process on the basis of their DTA results. These samples are carried out for XRD measurements in the $2 \theta$ range from 20 to $80^{\circ}$ to study the crystallization behaviour and phase formation of the glass ceramic samples. The scanning electron microscopy (SEM) of these glass ceramic samples has been carried out to explore the morphology through nucleation and growth of the crystallites in the glassy matrix. The values of dielectric constant as well as dielectric loss were increased with increasing the temperature within the frequency range from $20 \mathrm{~Hz}$ to $100 \mathrm{~Hz}$. The addition of $1 \mathrm{~mol} \%$ of $\mathrm{La}_{2} \mathrm{O}_{3}$ to the lead bismuth titanate glasses enhances the crystallization and acts as donor dopant for this glass system.

\section{Introduction}

Glasses are defined as inorganic product of fusion which has been cooled to a rigid condition without crystallization [1]. The main distinction between glass and crystal is the presence of long range order in the crystal structure. For many years glasses containing transition metal ions have attracted attention because of their potential application in electrochemical, electronic, and electro optics device [2]. Lead bismuth titanate (PBT) borosilicate glasses are analogous to the perovskite lead strontium titanate glass ceramics. The study of various oxide glasses has received considerable attention due to their structural property $[3,4]$. These glasses have wide application in the field of electronics, nuclear, and solar energy technologies and acoustic-optics device [5-9]. Glass ceramics are formed by controlled crystallization of glasses. Glass ceramics have become commercially important materials in the various fields such as consumer products, vacuum tube envelops, telescope mirror blanks, radomes for the aerospace industry, and protective coating for metals [10]. The properties and hence applications of glass ceramics depend on the complex interrelationship of structural, compositional, and processing variables [11]. Recently, a series of perovskite glass ceramics are investigated $[12,13]$. The glass ceramics of these systems were developed with the objective of producing materials for the electronic industry with high dielectric constants or optoelectronic effects. The controlled crystallization of the perovskite type lead titanate, $\mathrm{PbTiO}_{3}$, was first reported by Herczog and Stookey in the $\mathrm{SiO}_{2}-\mathrm{Al}_{2} \mathrm{O}_{3}-\mathrm{TiO}_{2}-\mathrm{PbO}$ system [14]. Glass ceramics containing undoped perovskite titanate such as $\mathrm{PbTiO}_{3}$ have been extensively investigated [15-22]. Bismuth based glasses are used to produce glass ceramic superconductors (high $T_{c}$ ) with controllable microstructure [23-28]. These glass 
ceramics have interesting dielectric properties, resulting from the combination of high-permittivity crystallites and lowpermittivity glassy matrix $[29,30]$. Various studies have been done on the glasses and their glass ceramic system $\left(\mathrm{Pb}_{x} \mathrm{Sr}_{1-x}\right) \cdot \mathrm{TiO}_{3}$ [31-33]. More recently, optical and electrical properties of $\left(\mathrm{Pb}_{x} \mathrm{Bi}_{1-x}\right) \cdot \mathrm{TiO}_{3}$ borosilicate glass and glass ceramic systems were extensively reported by Gautam et al. $[34,35]$.

The recent demand to increase the energy storage capability and reliability of capacitors is necessary for future application prospects. In recent years, significant efforts have been made to develop high dielectric constant materials, which are capable of a high energy storage density $[36,37]$. Among all glass ceramic materials investigated, lead bismuth titanate (PBT) glass ceramics have been found to be a promising candidate for high energy storage [38]. PBT glass ceramics are currently fabricated mainly in presence of borosilicate and aluminosilicate network forming systems with certain dopant such as $\mathrm{La}_{2} \mathrm{O}_{3}$ [39]. In the present paper, we report the synthesis, crystallization, and dielectric properties of $\mathrm{PBT}$ borosilicate glasses in the glass system $65\left[\left(\mathrm{~Pb}_{x} \mathrm{Bi}_{1-x}\right) \cdot \mathrm{TiO}_{3}\right]-$ $34\left[2 \mathrm{SiO}_{2} \cdot \mathrm{B}_{2} \mathrm{O}_{3}\right]-1 \mathrm{La}_{2} \mathrm{O}_{3}$.

\section{Experimental Procedure}

Various amorphous and transparent glasses in the glass system $65\left[\left(\mathrm{~Pb}_{x} \mathrm{Bi}_{1-x}\right) \cdot \mathrm{TiO}_{3}\right]-34\left[2 \mathrm{SiO}_{2} \cdot \mathrm{B}_{2} \mathrm{O}_{3}\right]-1 \mathrm{La}_{2} \mathrm{O}_{3}$ with $(0.0 \leq x \leq 1.0)$ doped with 1 percent $\mathrm{La}_{2} \mathrm{O}_{3}$ were synthesized successfully. Analytical reagent grade chemicals $\mathrm{PbO}$ (Fisher Scientific, 99\%), $\mathrm{Bi}_{2} \mathrm{O}_{3}$ (Himedia, 99.99\%), $\mathrm{TiO}_{2}$ (Himedia, 99\%), $\mathrm{SiO}_{2}$ (Himedia, 99.5\%), $\mathrm{H}_{3} \mathrm{BO}_{3}$ (Himedia, 99.8\%), and $\mathrm{La}_{2} \mathrm{O}_{3}$ (Himedia, 99.9\%) were well mixed for 3 hours in acetone media using mortar and pestle. The dried powders were melted in an alumina crucible at $1100^{\circ} \mathrm{C}$ and then quenched by pouring onto an aluminium mould and then immediately pressing with a thick aluminium plate. The glass was then annealed at $400^{\circ} \mathrm{C}$ for 3 hours and then furnace cooled to room temperature. The annealed glasses were cut by diamond cutter to get the desired shape of the samples. DTA was done using NETZSCH (Simultaneous Thermal Analyser 409) to determine the glass transition, $T_{g}$, and crystallization temperatures, $T_{c}$. Two sets of heat treatment conditions were used to convert glass into glass ceramics for 3 and 6 hours along with $5^{\circ} \mathrm{C} / \mathrm{min}$ heating rate. XRD patterns were taken using Rigaku Diffractometer employing $\mathrm{Cu} \mathrm{K} \alpha$ radiation over a $2 \theta$ range of $20^{\circ}-80^{\circ}$ at a scan rate of $4^{\circ} 2 \theta$ /minute to study the desired and secondary phases. For microstructure studies the samples were polished and etched using 30\% nitric acid and $20 \%$ hydrofluoric acid $\left(30 \% \mathrm{HNO}_{3}+20 \% \mathrm{HF}\right)$ solution for 30 seconds to 1 minute. After they were etched, the samples were cleaned by distilled water for 2 minutes to remove unwanted debris from the surface prior to gold coating and then dried in electric oven at $100^{\circ} \mathrm{C}$ to remove the water content from the samples. The SEM images are taken of gold coated glass ceramic samples using a JSM-840 scanning electron microscope (SEM) to study the morphology of different crystalline phases. For dielectric measurement of glass ceramic samples, both the surfaces of the samples were ground and polished using $\mathrm{SiC}$ powders for attaining smooth surfaces. The electrodes were made by applying silver paint on both sides of the specimen and curing at $450^{\circ} \mathrm{C}$ for $10 \mathrm{~min}$. The capacitance measurements were made in a locally fabricated sample holder using an automated measurement system during heating. The sample was mounted in the sample holder, which was kept in a programmable heating chamber. The leads from the sample holder were connected to HP 4284 A Precision LCR meter through scanner relay boards and HPIB bus, which in turn was connected to a computer and printer. Measurement operational controls and data recording are done through the computer. The sample was heated in the heating chamber to the required temperature at a rate of $2^{\circ} \mathrm{C} /$ minute. Capacitance, $\mathrm{C}$, and dissipation factor, D, of the samples were recorded at $20,100 \mathrm{~Hz}, 1,10$, and $100 \mathrm{kHz}$, and $1 \mathrm{MHz}$ at equal intervals of time during heating in the temperature range of room temperature to $500^{\circ} \mathrm{C}$.

\section{Nomenclature of the Samples}

The five letter glass codes refer to the composition of the glasses. First three letters PBT are designated to the content of lead bismuth titanate. The fourth letter $L$ indicates that 1 mole percent of $\mathrm{La}_{2} \mathrm{O}_{3}$ has been used as an additive, while the fifth letter, that is, $0.0,0.2,0.4,0.6,0.8$, or 1.0 , indicates the fraction of composition " $x$ " in the glass system. For the nomenclature of the glass ceramic samples, the following methodology has been adopted. First five letters in the codes for the glass ceramic sample are similar to the codes of their parent glasses and refer to the composition of glasses, and the next three digits indicate the crystallization temperature. The last letters $T$ and $S$ refer to the holding time for the crystallization temperatures for 3 and 6 hours. For example, in glass ceramic sample BTL0.0675T, the first two letters represent the amount of bismuth titanate, and third letter $L$ indicates that 1 mole percent of $\mathrm{La}_{2} \mathrm{O}_{3}$ has been taken as an additive, while 0.0 represents the value of composition like $(x=0.0)$, and three digit numbers 675 are representing the crystallization temperatures and $T$ indicates the 3-hour soaking time. The glass samples code along with their sample compositions has been listed in Table 1 .

\section{Result and Discussion}

4.1. X-Ray Diffraction Analysis of Glasses. The XRD pattern of the glass samples BTL0.0, PBTL0.2, and PBTL0.4 is shown in Figures 1(a), 1(b), and 1(c), respectively. These figures exhibit a very broad diffuse scattering at different angles along with different peak intensities instead of crystalline peaks, confirming short range structural order characteristics of glassy amorphous phase.

4.2. Differential Thermal Analysis (DTA). The DTA curves of the different glass samples BTL0.0, PBTL0.2, PBTL0.4, PBTL0.6, PBTL0.8, and PBTL1.0 are shown in Figures 2 and 3 , respectively. The glass transition temperature, $T_{g}$, and crystallization temperatures $\left(T_{c 1}, T_{c 2}\right)$ are listed in Table 1 along with the different composition of the glasses. $T_{g}$ values for all glass samples are lying from 587 to $637^{\circ} \mathrm{C}$. It is evident from Table 1 that the crystallization peak $T_{c 1}$ for all the DTA 


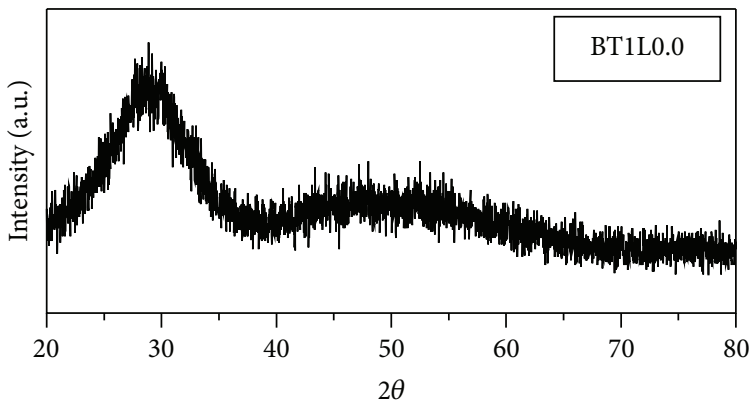

(a)

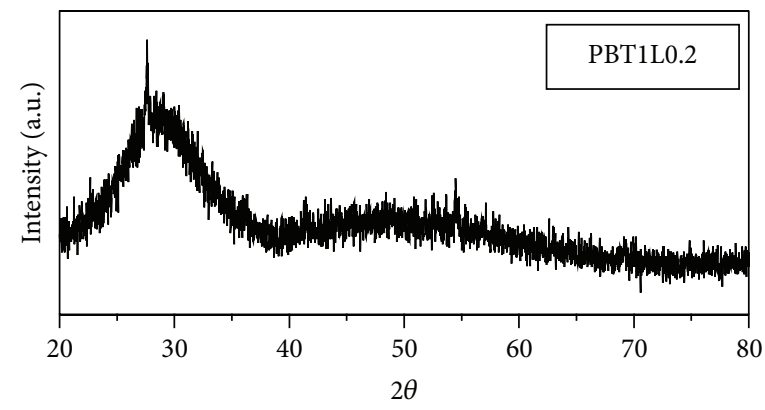

(b)

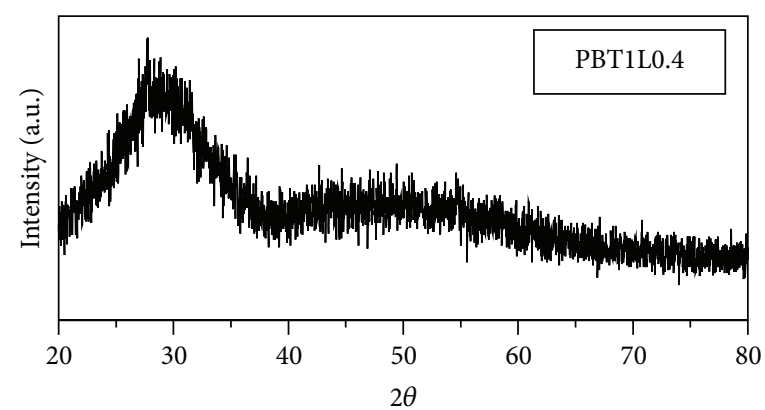

(c)

FIGURE 1: XRD pattern of glass samples: (a) BTL0.0, (b) PBTL0.2, and (c) PBTL0.4.

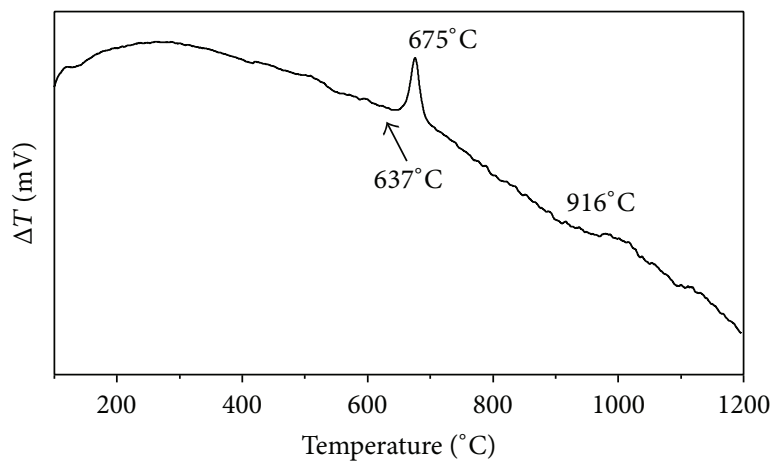

(a)

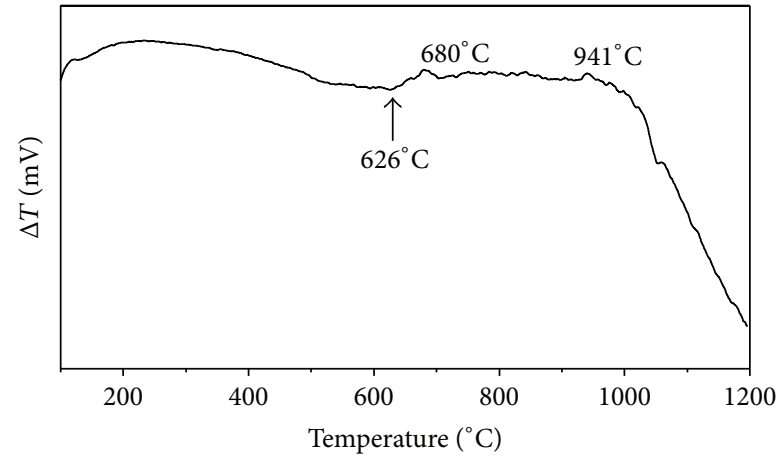

(b)

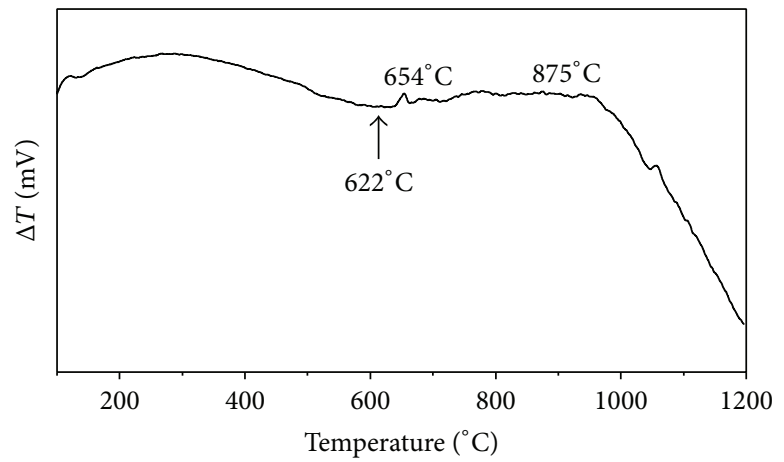

(c)

Figure 2: DTA pattern of the glass samples: (a) BTL0.0, (b) PBTL0.2, and (c) PBTL0.4 in the glass system $65\left[\left(\mathrm{~Pb}_{x} \mathrm{Bi}_{1-x}\right) \mathrm{TiO}_{3}\right]-34\left[2 \mathrm{SiO}_{2} \mathrm{~B}_{2} \mathrm{O}_{3}\right]-$ $1 \mathrm{La}_{2} \mathrm{O}_{3}$. 
TABLE 1: Nomenclature of glass samples, their compositional distribution, glass transition temperature, and DTA peaks of various glass samples in the system $65\left[\left(\mathrm{~Pb}_{x} \mathrm{Bi}_{1-x}\right) \cdot \mathrm{TiO}_{3}\right]-34\left[2 \mathrm{SiO}_{2} \mathrm{~B}_{2} \mathrm{O}_{3}\right]-1 \mathrm{La}_{2} \mathrm{O}_{3}$.

\begin{tabular}{|c|c|c|c|c|c|c|c|}
\hline \multirow{2}{*}{$\begin{array}{l}\text { Glass sample } \\
\text { code }\end{array}$} & \multirow{2}{*}{$x$} & \multicolumn{3}{|c|}{ Composition (wt \%) } & \multicolumn{3}{|c|}{ DTA peaks $\left({ }^{\circ} \mathrm{C}\right)$} \\
\hline & & $\left(\mathrm{Pb}_{x} \mathrm{Bi}_{1-x}\right) \mathrm{TiO}_{3}$ & $\left(2 \mathrm{SiO}_{2}-\mathrm{B}_{2} \mathrm{O}_{3}\right)$ & $\mathrm{La}_{2} \mathrm{O}_{3}$ & $T_{g}$ & $T_{c 1}$ & $T_{c 2}$ \\
\hline BTL0.0 & 0.0 & 65 & 34 & 1 & 637 & 675 & 916 \\
\hline PBTL0.2 & 0.2 & 65 & 34 & 1 & 626 & 680 & 941 \\
\hline PBTL0.4 & 0.4 & 65 & 34 & 1 & 622 & 654 & 875 \\
\hline PBTL0.6 & 0.6 & 65 & 34 & 1 & 602 & 619 & 630 \\
\hline PBTL0.8 & 0.8 & 65 & 34 & 1 & 599 & 621 & 777 \\
\hline PBTL1.0 & 1.0 & 65 & 34 & 1 & 587 & 593 & 810 \\
\hline
\end{tabular}

TABLE 2: Glass ceramic sample code, heating rate, holding time, holding temperature, crystallite size, and crystal structure in the glass system $65\left[\left(\mathrm{~Pb}_{x} \mathrm{Bi}_{1-x}\right) \cdot \mathrm{TiO}_{3}\right]-34\left[2 \mathrm{SiO}_{2} \mathrm{~B}_{2} \mathrm{O}_{3}\right]-1 \mathrm{La}_{2} \mathrm{O}_{3}$.

\begin{tabular}{lccccc}
\hline $\begin{array}{l}\text { Glass ceramic } \\
\text { sample code }\end{array}$ & $\begin{array}{c}\text { Heating rate } \\
\left({ }^{\circ} \mathrm{C} / \mathrm{min}\right)\end{array}$ & $\begin{array}{c}\text { Holding time } \\
\text { (hour) }\end{array}$ & $\begin{array}{c}\text { Holding } \\
\text { temperature }\left({ }^{\circ} \mathrm{C}\right)\end{array}$ & Crystallite size (nm) & Crystal structure \\
\hline BTL0.0675T & 5 & 3 & 675 & 675 & 7.28 \\
BTL0.0675S & 5 & 6 & 916 & 7.37 & Orthorhombic \\
BTL0.0916T & 5 & 3 & 916 & 5.80 & Orthorhombic \\
BTL0.0916S & 5 & 6 & 5.89 & Orthorhombic \\
\hline
\end{tabular}

patterns of the glass samples is decreased with increasing the value of " $x$ " in the glass system, because viscosity of the lead rich glass melts is less in comparison to the bismuth content glass melts as shown in Table 1. Figure 2(a) depicts the DTA pattern of the glass sample BTL0.0. It is observed from the DTA pattern of this glass sample that there are two exothermic peaks, $T_{c 1}$ and $T_{c 2}$, situated at different temperatures, 675 and $916^{\circ} \mathrm{C}$. The sharp peak $T_{c 1}$ occurs due to the major phase formation of bismuth titanium oxide $\left(\mathrm{Bi}_{4} \mathrm{Ti}_{3} \mathrm{O}_{12}\right)$ while peak $T_{c 2}$ is due to the secondary phase formation of bismuth oxoborate $\left(\mathrm{Bi}_{4} \mathrm{~B}_{2} \mathrm{O}_{9}\right)$, which is also confirmed from the XRD results. The DTA patterns of the glass samples PBTL0.2 and PBTL0.4 are also shown in Figures 2(b) and 2(c). Both the DTA patterns have similar behaviour and only difference is observed in their peaks positions $T_{c 1}$ and $T_{c 2}$. Figure 3(a) depicts the DTA pattern for the glass sample PBTL0.6 and showed a splitting in the exothermic peak at different temperatures, $619^{\circ} \mathrm{C}$ and $630^{\circ} \mathrm{C}$, respectively. Figures 3(b) and 3(c) represent the DTA pattern for the glass samples PBTL0.8 and PBTL1.0. The DTA patterns of these glass samples show the two types of peaks, that is, exothermic as well as endothermic. The peak positions, $T_{c 1}$ and $T_{c 2}$, at 621 and $777^{\circ} \mathrm{C}$ are observed due to major as well as secondary phase formations. The DTA pattern of glass sample PBTL1.0, which is lead-free $(x=1.0)$ (Figure 3(c)), has similar behaviour like DTA pattern of glass sample PBTL0.8, but only a difference has been observed in the peak nature of $T_{c 1}$.

4.3. Crystallization Behaviour of the Glass Ceramics. Glass ceramic sample code, heating rate, holding time, holding temperature, and crystallite size of these glass ceramic samples have been listed in Table 2. A tentative glass sample
BTL0.0 has been taken to crystallize it at two different temperatures, 675 and $916^{\circ} \mathrm{C}$, for 3- and 6-hour heat treatment schedule with a heating rate of $5^{\circ} \mathrm{C} / \mathrm{min}$. The XRD of these glass ceramic samples BTL0.0675T, BTL0.0675S, BTL0.0916T, and BTL0.0916S is shown in Figures 4(a), 4(b), 4(c), and 4(d), respectively. The XRD pattern has been indexed with JCPDS file card number 35-0795 and all the peaks were identified corresponding to the higher intensity peak having the value of $h k l$ (171) and marked properly as shown in their plots. Glass ceramic samples BTL0.0675T and BTL0.0675S show similar crystallization behaviour and are consisting of the major as well as pyrochlore phases while the same glass sample crystallized at higher temperature $916^{\circ} \mathrm{C}$ for 3- and 6-hour heat treatment schedules and the pyrochlore phase completely disappears and only a formation of the major phase of bismuth titanium oxide $\left(\mathrm{Bi}_{4} \mathrm{Ti}_{3} \mathrm{O}_{12}\right)$ is there. It is concluded that the observed major crystalline phase for all the glass ceramic samples is of bismuth titanium oxide $\left(\mathrm{Bi}_{4} \mathrm{Ti}_{3} \mathrm{O}_{12}\right)$ and the pyrochlore phase of bismuth oxoborate $\left(\mathrm{Bi}_{4} \mathrm{~B}_{2} \mathrm{O}_{9}\right)$. The reported results on $\mathrm{XRD}$ of the glass ceramic samples are showing orthorhombic crystal structure having different lattice parameters $a=5.393 \AA, b=32.723 \AA$, and $c=5.483 \AA$ (Table 2). The crystallite size from the XRD pattern was calculated by using Scherer formula [40]:

$$
\text { Crystallite size } D_{p}=\frac{K \lambda}{\beta \cos \theta} \text {, }
$$

where $K$ is the shape factor (0.94), $\lambda$ is wavelength of $\mathrm{Cu}-\mathrm{K} \alpha$ line $(1.54 \AA)$, and $\beta$ is full width at half maximum. The minimum and maximum values of crystallite size corresponding to maximum intensity peaks of glass ceramic 


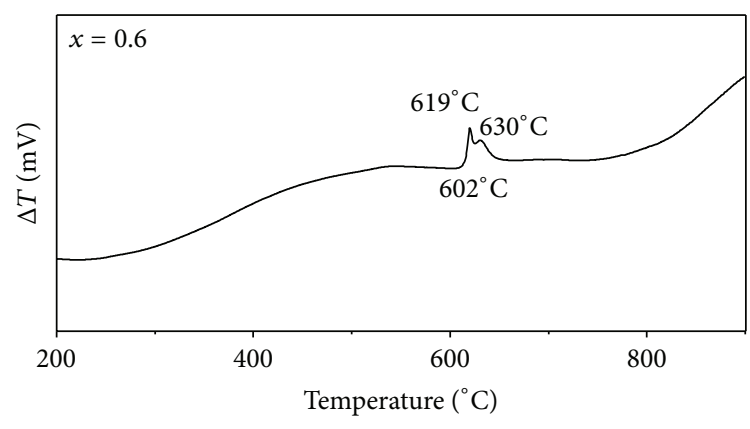

(a)

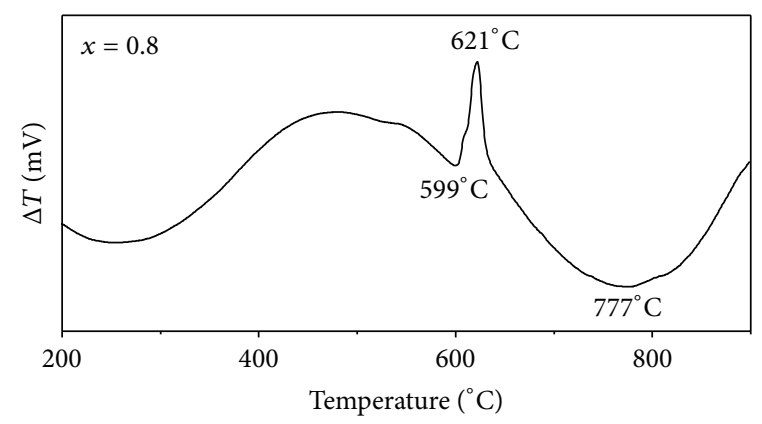

(b)

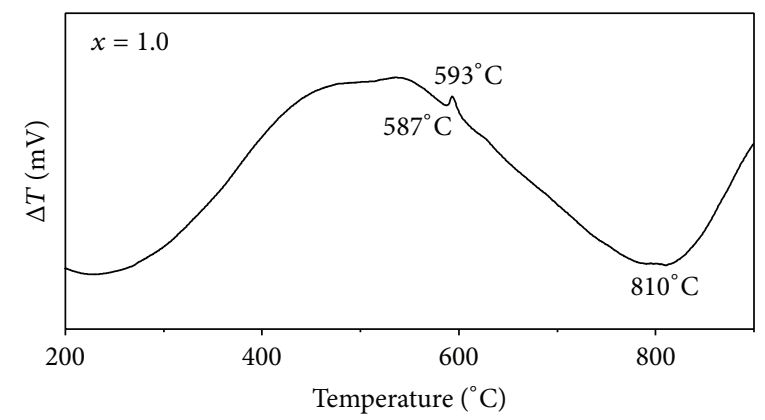

(c)

Figure 3: DTA pattern of the glass samples: (a) PBTL0.6, (b) PBTL0.8, and (c) PBTL1.0 in the glass system $65\left[\left(\mathrm{~Pb}_{x} \mathrm{Bi}_{1-x}\right) \mathrm{TiO}_{3}\right]-$ $34\left[2 \mathrm{SiO}_{2} \mathrm{~B}_{2} \mathrm{O}_{3}\right]-1 \mathrm{La}_{2} \mathrm{O}_{3}$.

samples BTL0.0916T and BTL0.0675S have been found $5.80 \mathrm{~nm}$ and $7.37 \mathrm{~nm}$, respectively.

4.4. Scanning Electron Microscopic Analysis. The surface morphology of all glass ceramic samples shows fine crystallites of major phases of bismuth titanium oxide $\left(\mathrm{Bi}_{4} \mathrm{Ti}_{3} \mathrm{O}_{12}\right)$. Qualitative inspection of all these SEM micrographs reveals that the relative content of residual glass phase is present in large amount except the SEM micrograph of glass ceramic sample PBTL0.4875S. The coexistence of coarse and fine particles has been also observed in all the glass ceramic sample micrographs similar to the lead titanate based glass ceramics [41, 42]. Figure 5(a) shows that the scanning electron micrograph of glass ceramic sample BTL0.0916T is found to be composed of interconnected fine and uniform crystallites of bismuth titanium oxide $\left(\mathrm{Bi}_{4} \mathrm{Ti}_{3} \mathrm{O}_{12}\right)$. Crystallites are well dispersed in the glassy matrix and separated by developed grain boundaries throughout the micrograph. Figures 5(b) and 5(c) show the scanning electron micrographs of glass ceramic samples PBTL0.2941T and PBTL0.2941S, respectively, and there is a change in the morphology of the crystallites of the major phase $\mathrm{Bi}_{4} \mathrm{Ti}_{3} \mathrm{O}_{12}$. These crystallites are found to have irregular shape and not uniformly distributed in the glassy matrix. The glass ceramic sample PBTL0.4654T (Figure 5(d)) shows the small crystallites which are not properly developed in the glassy matrix and have the crystallite size of the order of $533 \mathrm{~nm}$. Figures 5(e) and 5(f) depict the SEM micrographs of the glass ceramic samples PBTL0.4875T and PBTL0.4875S. The morphology of the crystallites is entirely different and mainly they are differing in terms of the crystal growth and their distribution. The crystal growths for the glass ceramic sample PBTL0.4875S are well developed in comparison to the glass ceramic sample PBTL0.4875T which is crystallized for 3 hours. It means that the soaking time for the crystallization of these glass ceramic samples strongly influences the nucleation and growth of the crystals. In some of the micrographs, agglomeration of the crystallites has been also observed. Glass ceramic sample codes, heating rate, holding time, holding temperature, and grain size of the synthesized glass ceramic samples in the glass system $65\left[\left(\mathrm{~Pb}_{x} \mathrm{Bi}_{1-x}\right) \cdot \mathrm{TiO}_{3}\right]$ $34\left[2 \mathrm{SiO}_{2} \mathrm{~B}_{2} \mathrm{O}_{3}\right]-1 \mathrm{La}_{2} \mathrm{O}_{3}$ have been listed in Table 3. It is also observed that the size of the grains increased with increasing the soaking time from 3 to 6 hours. The minimum and maximum values of the grain size of the glass ceramic samples, PBTL0.4875T and PBTL0.4875S, have been found $330 \mathrm{~nm}$ and $750 \mathrm{~nm}$, respectively (Table 3 ).

4.5. Dielectric Characteristics. The variation of the dielectric constant, $\varepsilon_{r}$, and dissipation factor, $D$, were measured as a function of temperature within the temperature range from 50 to $500^{\circ} \mathrm{C}$ at few selected frequencies such as 20 , $100 \mathrm{~Hz}, 1,10$, and $100 \mathrm{kHz}$, and $1 \mathrm{MHz}$ for the tentative glass ceramic samples PBTL0.2941T and PBTL0.4875T. Figure 6 shows the variations of $\varepsilon_{r}$ and $D$ with temperature for glass ceramic sample PBTL0.2941T. The value of $\varepsilon_{r}$ has been found to increase with increasing temperature at low frequency range from $20 \mathrm{~Hz}$ to $100 \mathrm{~Hz}$, while the value of $\varepsilon_{r}$ is found constant, which means that temperature is independent of the higher frequency range. The value of dielectric constant was found to be a maximum at a frequency of $20 \mathrm{~Hz}$. At 


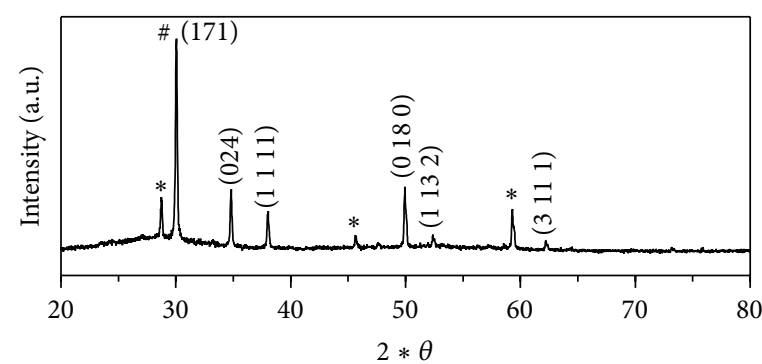

\# Bismuth titanium oxide $\left(\mathrm{Bi}_{4} \mathrm{Ti}_{3} \mathrm{O}_{12}\right)$

* Bismuth oxoborate $\left(\mathrm{Bi}_{4} \mathrm{~B}_{2} \mathrm{O}_{9}\right)$

(a)

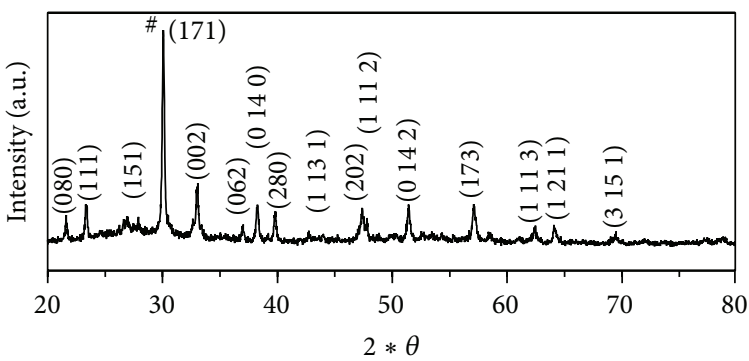

\# Bismuth titanium oxide $\left(\mathrm{Bi}_{4} \mathrm{Ti}_{3} \mathrm{O}_{12}\right)$

(c)

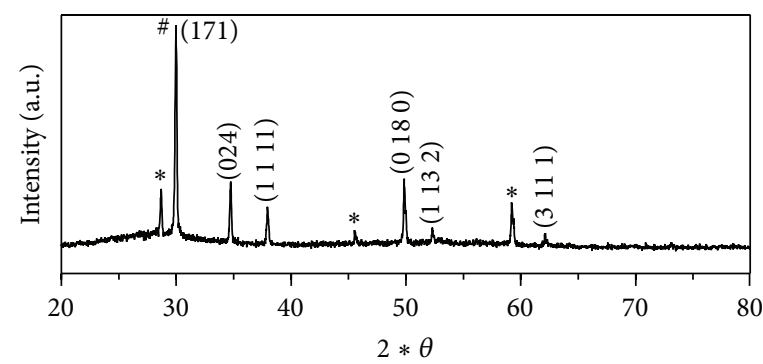

\# Bismuth titanium oxide $\left(\mathrm{Bi}_{4} \mathrm{Ti}_{3} \mathrm{O}_{12}\right)$

* Bismuth oxoborate $\left(\mathrm{Bi}_{4} \mathrm{~B}_{2} \mathrm{O}_{9}\right)$

(b)

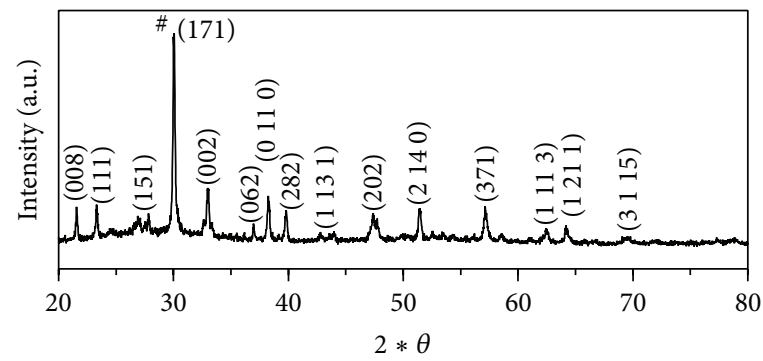

\# Bismuth titanium oxide $\left(\mathrm{Bi}_{4} \mathrm{Ti}_{3} \mathrm{O}_{12}\right)$

(d)

FIGURE 4: XRD pattern of glass ceramic samples: (a) BTL0.0675T, (b) BTL0.0675S, (c) BTL0.0916T, and (d) BTL0.0916S.

TABLE 3: Glass ceramic sample code, heating rate, holding time, holding temperature, and average grain size in the glass system $65\left[\left(\mathrm{~Pb}_{x} \mathrm{Bi}_{1-x}\right) \cdot \mathrm{TiO}_{3}\right]-34\left[2 \mathrm{SiO}_{2} \mathrm{~B}_{2} \mathrm{O}_{3}\right]-1 \mathrm{La}_{2} \mathrm{O}_{3}$.

\begin{tabular}{lcccc}
\hline $\begin{array}{l}\text { Glass ceramic } \\
\text { sample code }\end{array}$ & Heating rate $\left({ }^{\circ} \mathrm{C} / \mathrm{min}\right)$ & $\begin{array}{l}\text { Heat treatment schedule } \\
\text { Holding time }(\text { hour })\end{array}$ & Holding temperature $\left({ }^{\circ} \mathrm{C}\right)$ & Grain size $(\mathrm{nm})$ \\
\hline BTL0.0916T & 5 & 3 & 916 & 375 \\
PBTL0.2941T & 5 & 3 & 941 & 420 \\
PBTL0.2941S & 5 & 6 & 654 & 600 \\
PBTL0.4654T & 5 & 3 & 875 & 333 \\
PBTL0.4875T & 5 & 3 & 875 & 750 \\
PBTL0.4875S & 5 & 6 & & 30 \\
\hline
\end{tabular}

higher frequencies, the dielectric constant is invariant due to a reduction of the net polarization. This can be explained by the Maxwell-Wagner model of the dielectric constant [43]. The maximum value of dielectric constant $\varepsilon_{r}$ is found to be the order of 70,000. The dielectric loss for PBTL0.2941T was also increased with increasing temperature at low frequency range from $20 \mathrm{~Hz}$ to $100 \mathrm{~Hz}$. The addition of $1 \mathrm{~mol} \% \mathrm{La}_{2} \mathrm{O}_{3}$ to the PBT glasses promotes the crystallization, as discussed earlier in the crystallization kinetics. $\mathrm{La}^{3+}$ ions form $\mathrm{La}_{2} \mathrm{O}_{3}$ which are present in the glassy network and they are diffused into the crystalline phase of PBT at higher temperatures during the heat treatment processes. These ions of $\mathrm{La}^{3+}$ make them semiconducting in nature. SEM of the sample PBTL0.2941T showed a change in the morphology of the crystallites of the major phase $\mathrm{Bi}_{4} \mathrm{Ti}_{3} \mathrm{O}_{12}$. These crystallites are found to have irregular shape and not uniformly distributed in the glassy matrix. Hence, a large conductivity difference is introduced between the semiconducting grains and insulating grainboundary. The conductivity difference is responsible for space charge polarization and hence the effective value of dielectric constant [44]. The order of the dielectric constant, $\varepsilon_{r}$, was higher than that reported earlier for $\mathrm{La}_{2} \mathrm{O}_{3}$ doped PBT glass ceramics [45]. Figure 7 shows the plots of dielectric constant $\varepsilon_{r}$ and dissipation factor $D$ versus temperature for the glass ceramic sample PBTL0.4875T; both plots have similar trends. The pattern shows that the dielectric constant increases gradually at 20 and $100 \mathrm{~Hz}$ with increasing temperature and remains invariant at other frequencies. The dielectric loss also increased gradually with increasing temperature. A signature of a broad peak has been observed in the dielectric plot at $20 \mathrm{~Hz}$ and $500^{\circ} \mathrm{C}$ having the very high value of $\varepsilon_{r}$ which is the order of 80,000 and maybe it becomes more broadened at higher temperature. The dielectric constant $\varepsilon_{r}$ was invariant up to $200^{\circ} \mathrm{C}$ at lower frequencies and was independent of 


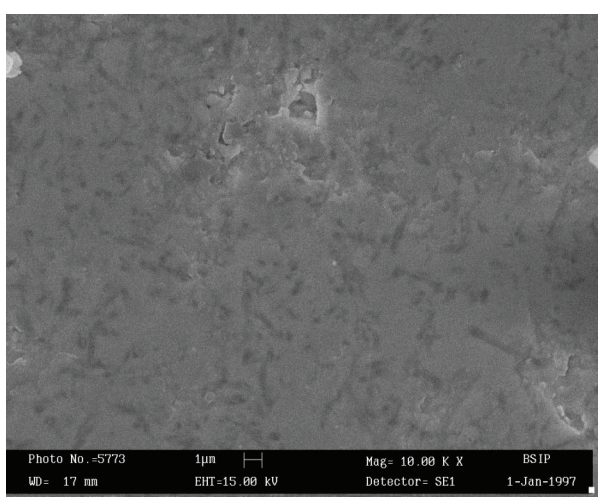

(a)

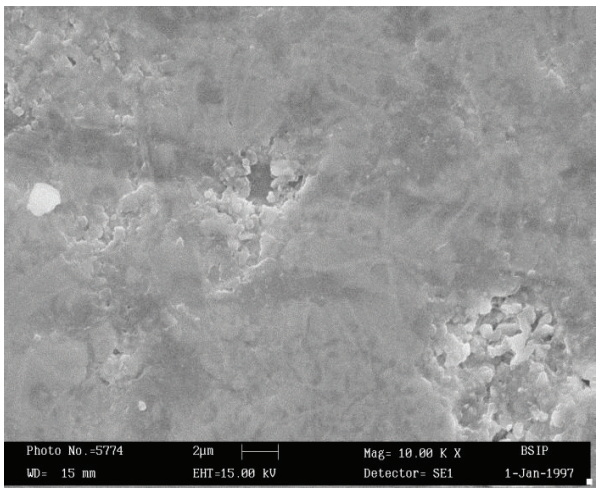

(c)

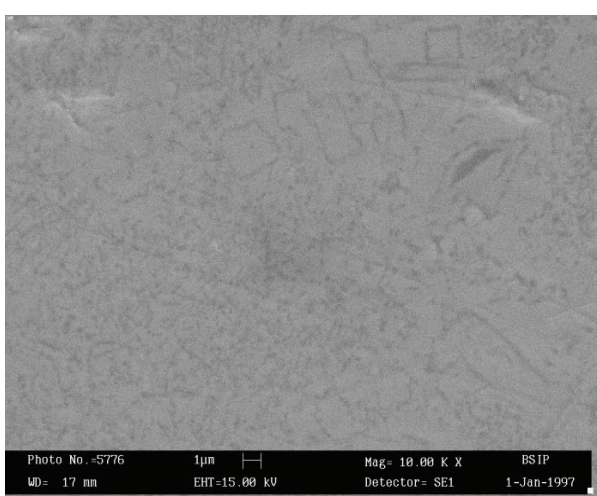

(e)

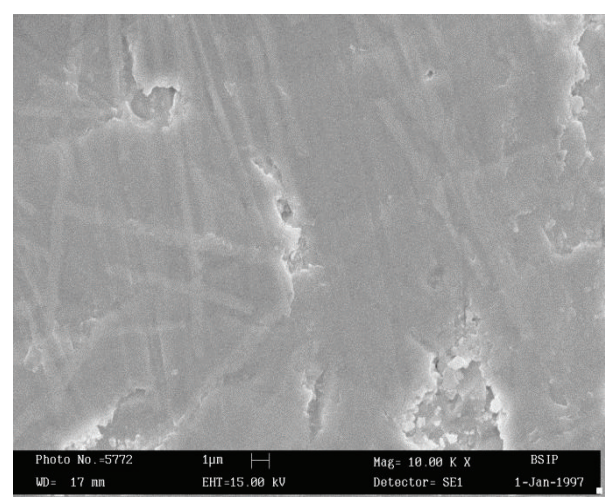

(b)

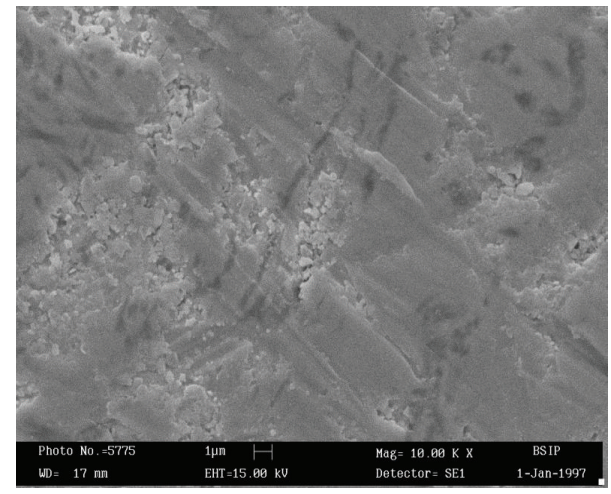

(d)

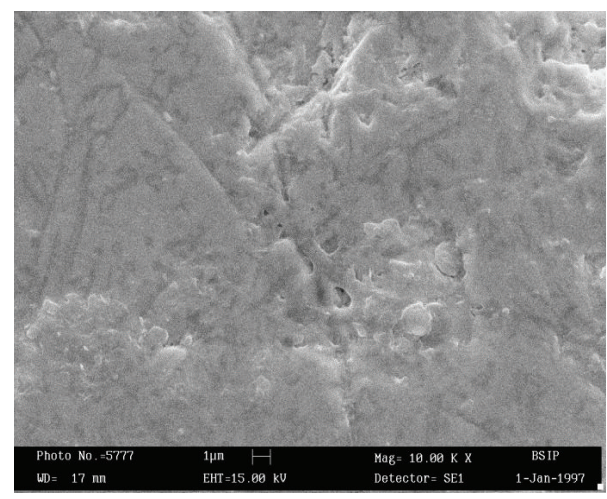

(f)

FIGURE 5: SEM micrographs of glass ceramic samples: (a) BTL0.0916T, (b) PBTL0.2941T, (c) PBTL0.2941S, (d) PBTL0.4654T, (e) PBTL0.4875T, and (f) PBTL0.4875S.

temperature at higher frequencies. The dielectric constant was strongly dependent on the composition and increased with the addition of $\mathrm{PbO}$ in place of $\mathrm{Bi}_{2} \mathrm{O}_{3}$ in the glassy matrix. The dielectric loss was found to be low in this glass ceramic system. The low dielectric loss was attributed to the addition of $\mathrm{La}^{3+}$ ions in the glassy matrix, which have smaller ionic radii than that of $\mathrm{Ti}^{4+}$ ions. $\mathrm{La}^{3+}$ ions act as acceptor ions and are very useful in reducing $\mathrm{Ti}^{4+}$ ions. $\mathrm{La}^{3+}$ ions may even substitute for $\mathrm{Ti}^{4+}$ sites and prevent the reduction of $\mathrm{Ti}^{4+}$ to $\mathrm{Ti}^{3+}$ by neutralizing the donor action of the oxygen vacancies, causing a decrease in the dielectric loss $[46,47]$. If we compare our investigated results with earlier reported results on crystallization and dielectric behaviors of perovskite $(\mathrm{Ba}, \mathrm{Sr}) \mathrm{TiO}_{3}$ borosilicate glass ceramics it is observed that replacement of bismuth oxide in place of strontium oxide with doping of $\mathrm{La}_{2} \mathrm{O}_{3}$ enhanced the values of dielectric constant as well as dielectric loss [48, 49].

\section{Conclusions}

DTA pattern of the glass samples BTL0.0, PBTL0.2, and PBTL0.4 shows only two exothermic peaks while the rest of glass ceramic samples show the exothermic as well as endothermic peaks. The values of all exothermic peaks, $T_{c 1}$, 


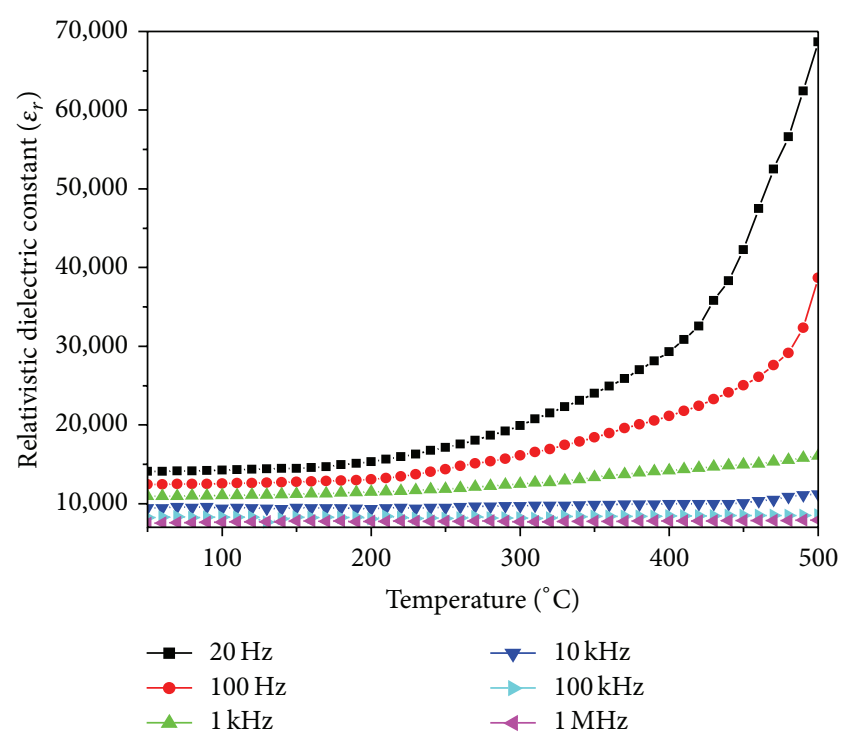

(a)

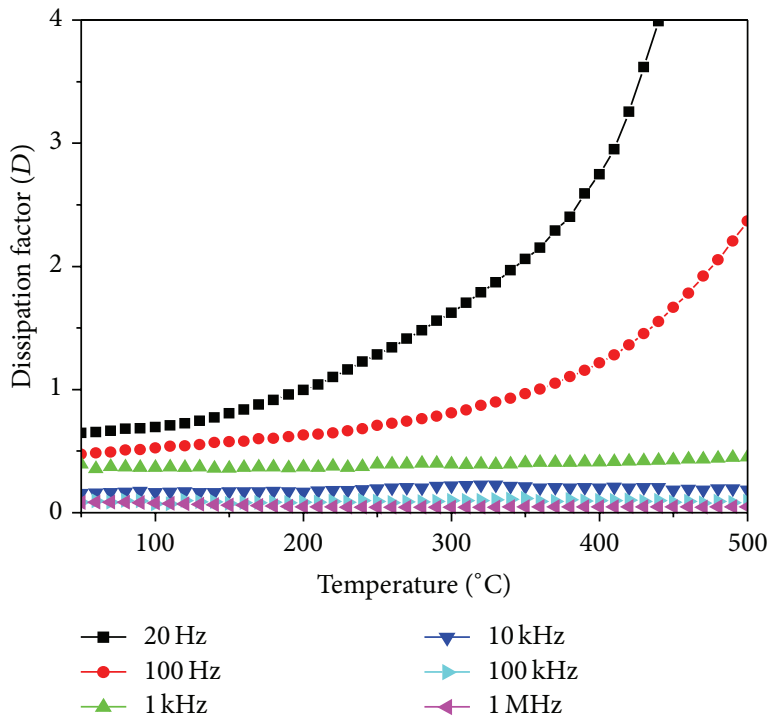

(b)

FIGURE 6: Variation of (a) dielectric constant and (b) dissipation factor with temperature at different frequencies for the glass ceramic sample PBTL0.2941T.

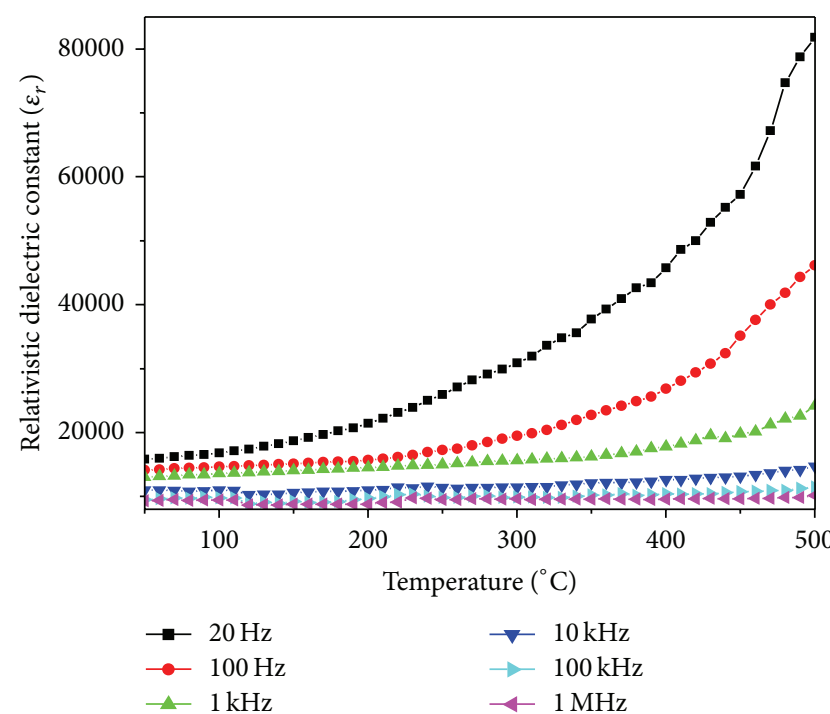

(a)

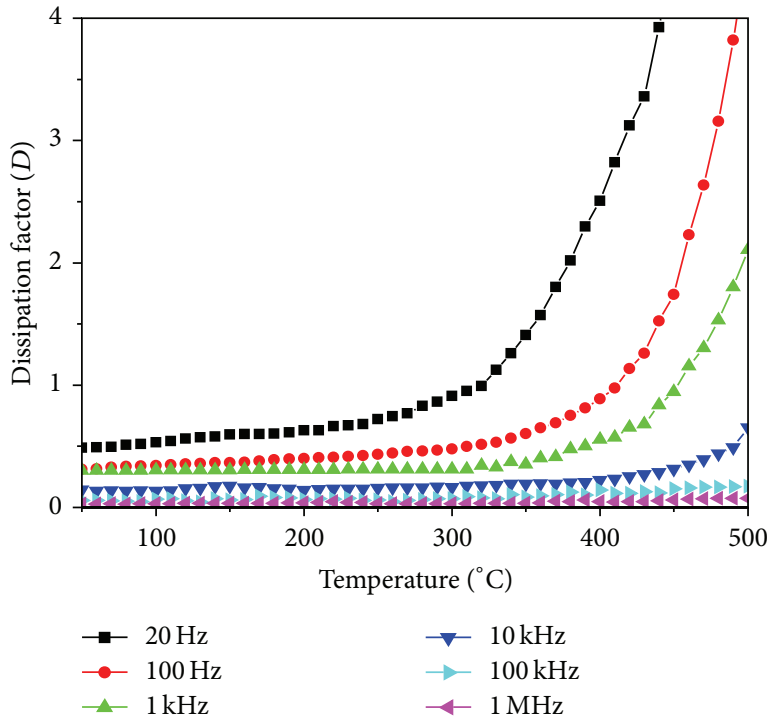

(b)

FIGURE 7: Variation of (a) dielectric constant and (b) dissipation factor with temperature at different frequencies for the glass ceramic sample PBTL0.4875T.

for all glass samples shift towards lower temperature side due to the different melting temperature and viscosity of the melts. The glass transition temperature, $T_{g}$, decreases as decreasing the amount of $\mathrm{Bi}_{2} \mathrm{O}_{3} \cdot \mathrm{Bi}_{2} \mathrm{O}_{3}$ helps in the promotion of the nucleation and growth add acts as nucleating agent. It is concluded that the major phase of bismuth titanium oxide $\left(\mathrm{Bi}_{4} \mathrm{Ti}_{3} \mathrm{O}_{12}\right)$ crystallized along with pyrochlore phase of bismuth oxoborate $\left(\mathrm{Bi}_{4} \mathrm{~B}_{2} \mathrm{O}_{9}\right)$. The pyrochlore phase of bismuth oxoborate $\left(\mathrm{Bi}_{4} \mathrm{~B}_{2} \mathrm{O}_{9}\right)$ disappeared when the same glass samples crystallized at higher temperature $916^{\circ} \mathrm{C}$. XRD patterns of these glass ceramic samples show orthorhombic crystal structure. The effect of heat treatment schedule for 3 and 6 hours changes the surface morphology of the crystallites. Very high value of dielectric constant of the order of 80,000 was found for 3-hour heat treated glass ceramic sample. The high dielectric constant was due to space charge polarization, which was attributed to the conductivity difference between the semiconducting grains and the insulating 
grain-boundary in the glass matrix. $\mathrm{La}_{2} \mathrm{O}_{3}$ plays an important role as a nucleating agent for such type of glass ceramic samples.

\section{Conflict of Interests}

The authors declare that there is no conflict of interests regarding the publication of this paper.

\section{Acknowledgments}

The author Dr. C. R. Gautam gratefully acknowledges the Uttar Pradesh Council of Science and Technology, Lucknow, India, for financial support under the "Young Scientist Scheme" as major research Project no. CSTT/YSS/D-3913. The authors are also thankful to Professor R. K. Shukla, University of Lucknow, Lucknow, India, for providing the dielectric measurement facilities.

\section{References}

[1] M. Yamane and Y. Asahara, Glasses for Photonics, Cambridgve Uniersity Press, Cambridge, UK, 2000.

[2] S. Murugavel and B. Roling, "Ion transport mechanism in borate glasses: influence of network structure on non-Arrhenius conductivity," Physical Review B, vol. 76, no. 18, Article ID 180202, 4 pages, 2007.

[3] E. I. Kamitsos and M. A. Karakassides, "Structural studies of binary and pseudo binary sodium borate glasses of high sodium content," Physics and Chemistry of Glasses, vol. 30, no. 1, pp. 1926, 1989.

[4] S. G. Motke, S. P. Yawale, and S. S. Yawale, "Infrared spectra of zinc doped lead borate glasses," Bulletin of Materials Science, vol. 25, no. 1, pp. 75-78, 2002.

[5] V. Rajendran, N. Palanivelu, H. A. El-Batal, F. A. Khalifa, and N. A. Shaft, "Effect of $\mathrm{Al}_{2} \mathrm{O}_{3}$ addition on the acoustical properties of lithium borate glasses," Acoustics Letters, vol. 23, no. 6, pp. 113-121, 1999.

[6] H. Hirashima, D. Arai, and T. Yoshida, "Electrical conductivity of $\mathrm{PbO}-\mathrm{P}_{2} \mathrm{O}_{5} \mathrm{~V}_{2} \mathrm{O}_{5}$ glasses," Journal of the American Ceramic Society, vol. 68, no. 9, pp. 486-489, 1985.

[7] A. Khanna, S. S. Bhatti, K. J. Singh, and K. S. Thind, "Gammaray attenuation coefficients in some heavy metal oxide borate glasses at $662 \mathrm{keV}$," Nuclear Instruments and Methods in Physics Research Section B, vol. 114, no. 3-4, pp. 217-220, 1996.

[8] K. Singh, H. Singh, V. Sharma et al., "Gamma-ray attenuation coefficients in bismuth borate glasses," Nuclear Instruments and Methods in Physics Research, Section B: Beam Interactions with Materials and Atoms, vol. 194, no. 1, pp. 1-6, 2002.

[9] A. Khanna, A. Saini, B. Chen, F. González, and B. Ortiz, "Structural characterization of $\mathrm{PbO}-\mathrm{B}_{2} \mathrm{O}_{3}-\mathrm{SiO}_{2}$ glasses," Physics and Chemistry of Glasses: European Journal of Glass Science and Technology Part B, vol. 55, no. 2, pp. 65-73, 2014.

[10] A. Abou Shama and F. H. El-Batal, "Structural analysis of glassy lead borate containing $\mathrm{MoO}_{3}$ in relation to its optical properties," Egyptian Journal of Solids, vol. 29, pp. 49-67, 2006.

[11] P. W. McMillan, Glass Ceramics, Academic Press, New York, NY, USA, 2nd edition, 1979.

[12] C. R. Gautam, A. K. Yadav, and P. Singh, "Synthesis, crystallisation and microstructural study of perovskite $(\mathrm{Ba}, \mathrm{Sr}) \mathrm{TiO}_{3}$ borosilicate glass ceramic doped with $\mathrm{La}_{2} \mathrm{O}_{3}$," Materials Research Innovations, vol. 17, no. 3, pp. 148-153, 2013.

[13] C. R. Gautam, D. Kumar, and O. Parkash, "Controlled crystallization of $(\mathrm{Pb}, \mathrm{Sr}) \mathrm{TiO}_{3}$ borosilicate glass ceramics doped with $\mathrm{Nb}_{2} \mathrm{O}_{5}$," Glass Physics and Chemistry, vol. 39, no. 2, pp. 162-173, 2013.

[14] A. Herczog and S. D. Stookey, "Application of glass-ceramics for electronic components and circuits," US Pat. No. 30, pp. 413, 1960.

[15] C. G. Bergeron and C. K. Russell, "Nucleation and growth of lead titanate from a glass," Journal of the American Ceramic Society, vol. 48, pp. 115-118, 1965.

[16] D. G. Grossman and J. O. Isard, "Lead titanate glass-ceramics," Journal of the American Ceramic Society, vol. 52, no. 4, pp. 230231, 1969.

[17] D. G. Grossman and J. O. Isard, "Crystal clamping in $\mathrm{PbTiO}_{3}$ glass-ceramics," Journal of Materials Science, vol. 4, no. 12, pp. 1059-1063, 1969.

[18] S. M. Lynch and J. E. Shelby, "Crystal clamping in lead titanate glass-ceramics," Journal of the American Ceramic Society, vol. 67, no. 6, pp. 424-427, 1984.

[19] T. Kokubo and M. Tashiro, "Dielectric properties of finegrained $\mathrm{PbTiO}_{3}$ crystals precipitated in a glass," Journal of NonCrystalline Solids, vol. 13, no. 2, pp. 328-340, 1974.

[20] W. U. Mianxue and Z. Peinan, "Piezoelectricity, pyroelectricity and ferroelectricity in glass ceramics based on $\mathrm{PbTiO}_{3}$," Journal of Non-Crystalline Solids, vol. 84, no. 1-3, pp. 344-351, 1986.

[21] J.-J. Shyu and Y.-S. Yang, "Crystallization of a PbO-BaO-TiO ${ }_{2}$ $\mathrm{Al}_{2} \mathrm{O}_{3}-\mathrm{SiO}_{2}$ glass," Journal of the American Ceramic Society, vol. 78, no. 6, pp. 1463-1468, 1995.

[22] K. Saegusa, " $\mathrm{PbTiO}_{3}-\mathrm{PbO}-\mathrm{B}_{2} \mathrm{O}_{3}$ glass-ceramics by a sol-gel process," Journal of the American Ceramic Society, vol. 79, no. 12, pp. 3282-3288, 1996.

[23] T. Komatsu, R. Sato, K. Imai, K. Matusita, and T. Yamashita, "High $\mathrm{T}_{\mathrm{C}}$ superconducting glass ceramics based on the Bi-CaSi-Cu-O system," Japanese Journal of Applied Physics, vol. 27, no. 4, pp. 550-552, 1988.

[24] T. Minami, Y. Akamatsu, M. Tatsumisago, N. Toghe, and Y. Kowada, "Glass formation of high- $\mathrm{T}_{c}$ compound Bi.Ca.Sr by rapid quenching," Japanese Journal of Applied Physics, vol. 27, no. 5, pp. L777-L778, 1988.

[25] H. Zheng and J. D. MacKenzie, " $\mathrm{Bi}_{4} \mathrm{Sr}_{3} \mathrm{Ca}_{3} \mathrm{Cu}_{4} \mathrm{O}_{16}$ glass and superconducting glass ceramics," Physical Review B, vol. 38, no. 10, pp. 7166-7168, 1988.

[26] M. Tatsumisago, S. Tsuboi, N. Toghe, and T. Minami, "Formation of high $\mathrm{T}_{\mathrm{c}}$ superconductors from rapidly quenched Pb.Ca.Sr glasses," Journal of Non-Crystalline Solids, vol. 124, no. 2-3, pp. 167-173, 1990.

[27] M. Onisi, M. Kyoto, and M. Watanabe, "Properties of Bi$\mathrm{Pb}-\mathrm{Sr}-\mathrm{Ca}-\mathrm{Cu}-\mathrm{O}$ glass-ceramic fibers formed by glass-drawing method," Japanese Journal of Applied Physics, vol. 30, no. 6, p. L988, 1991.

[28] L. R. Yuan, K. Kurosawa, Y. Takigawa et al., "Pb-amount dependence of copper and oxygen valence in $\mathrm{Pb}$-doped $\mathrm{Bi}-\mathrm{Sr}$ $\mathrm{Ca}-\mathrm{Cu}-\mathrm{O}$ superconductors," Japanese Journal of Applied Physics, vol. 30, no. 9, pp. L1545-L1548, 1991.

[29] J. R. MacDonald, Impedance Spectroscopy, Wiley, New York, NY, USA, 1987.

[30] R. Gerhardt and A. S. Nowick, "The grain boundary conductivity effect in ceria doped with various trivalent cations. Part IElectrical behaviour," Journal of the American Ceramic Society, vol. 69, no. 9, pp. 641-646, 1986. 
[31] C. R. Gautam, P. Singh, O. P. Thakur, D. Kumar, and O. Parkash, "Synthesis, structure and impedance spectroscopic analysis of $\left[\left(\mathrm{Pb}_{x} \mathrm{Sr}_{1-x}\right) \cdot \mathrm{OTiO}{ }_{2}\right]-\left[\left(2 \mathrm{SiO}_{2} \cdot \mathrm{B}_{2} \mathrm{O}_{3}\right)\right]-7[\mathrm{BaO}]-\left[\mathrm{K}_{2} \mathrm{O}\right]$ glass ceramic system doped with $\mathrm{La}_{2} \mathrm{O}_{3}$," Journal of Materials Science, vol. 47, no. 18, pp. 6652-6664, 2012.

[32] C. Gautam, S. Dixit, and A. Madheshiya, "Synthesis and structural properties of lead strontium titanate borosilicate glasses with addition of chromium trioxide and graphene nanoplatlets," Spectroscopy Letters, vol. 48, no. 4, pp. 280-285, 2015.

[33] C. R. Gautam, D. Kumar, O. Parkash, and P. Singh, "Synthesis, IR, crystallization and dielectric study of $(\mathrm{Pb}, \mathrm{Sr}) \mathrm{TiO}_{3}$ borosilicate glass-ceramics," Bulletin of Materials Science, vol. 36, no. 3, pp. 461-469, 2013.

[34] C. R. Gautam, A. K. Singh, and A. K. Yadav, "Synthesis and optical characterization of $(\mathrm{Pb}, \mathrm{Bi}) \mathrm{TiO}_{3}$ borosilicate glass system," International Journal of Applied and Natural Sciences, vol. 1, pp. 69-74, 2012.

[35] C. R. Gautam, "Synthesis, structural and optical investigations of $(\mathrm{Pb}, \mathrm{Bi}) \mathrm{TiO}_{3}$ borosilicate glasses," Physics Research International, vol. 2014, Article ID 606709, 7 pages, 2014.

[36] Q. Tan, P. Irwin, and Y. Cao, "Advanced dielectrics for capacitors," IEEJ Transactions on Fundamentals and Materials, vol. 126, no. 11, pp. 1153-1159, 2006.

[37] M.-J. Pan and C. Randall, "A brief introduction to ceramic capacitors," IEEE Electrical Insulation Magazine, vol. 26, no. 3, pp. 44-50, 2010.

[38] Y. Zhang, T. Ma, X. Wang, Z. Yuan, and Q. Zhang, "Two dielectric relaxation mechanisms observed in lanthanum doped barium strontium titanate glass ceramics," Journal of Applied Physics, vol. 109, no. 8, Article ID 084115, 2011.

[39] A. K. Yadav and C. R. Gautam, "Successive relaxor ferroelectric behavior in la modified ( $\mathrm{Ba}, \mathrm{Sr}) \mathrm{TiO}_{3}$ borosilicate glass ceramics," Journal of Materials Science: Materials in Electronics, vol. 25, no. 8, pp. 3532-3536, 2014.

[40] A. L. Patterson, "The scherrer formula for X-ray particle size determination," Physical Review, vol. 56, no. 10, pp. 978-982, 1939.

[41] A. K. Sahu, D. Kumar, and O. Parkash, "Crystallization of lead strontium titanate perovskite phase in $\left[\left(\mathrm{Pb}_{1-x} \mathrm{Sr}_{x}\right) \mathrm{O} \cdot \mathrm{TiO}_{2}\right]$ $-\left[2 \mathrm{SiO}_{2} \cdot \mathrm{B}_{2} \mathrm{O}_{3}\right]-\left[\mathrm{K}_{2} \mathrm{O}\right]$ glass ceramics," Advances in Applied Ceramics, vol. 102, pp. 139-147, 2003.

[42] A. Bahrami, Z. A. Nemati, P. Alizadeh, and M. Bolandi, "Crystallization and electrical properties of $\left[\left(\mathrm{Pb}_{1-x} \mathrm{Sr}_{x}\right) \cdot \mathrm{TiO}_{3}\right]\left[\left(2 \mathrm{SiO}_{2}\right.\right.$ $\left.\left.\cdot \mathrm{B}_{2} \mathrm{O}_{3}\right)\right]\left[\mathrm{K}_{2} \mathrm{O}\right]$ glass-ceramics," Journal of Materials Processing Technology, vol. 206, no. 1-3, pp. 126-131, 2008.

[43] G. Catalan, D. O’Neill, R. M. Bowman, and J. M. Gregg, "Relaxor features in ferroelectric superlattices: a MaxwellWagner approach," Applied Physics Letters, vol. 77, no. 19, pp. 3078-3080, 2000.

[44] D. Kumar, C. R. Gautam, and O. Parkash, "Preparation and dielectric characterization of ferroelectric $\left(\mathrm{Pb}_{x} \mathrm{Sr}_{1-x}\right) \mathrm{TiO}_{3}$ glass ceramics doped with $\mathrm{La}_{2} \mathrm{O}_{3}$," Applied Physics Letters, vol. 89, Article ID 112908, 2006.

[45] C. R. Gautam, A. Madheshiya, and R. Mazumder, "Preparation, crystallization, microstructure and dielectric properties of lead bismuth titanate borosilicate glass ceramics," Journal of Advanced Ceramics, vol. 3, no. 3, pp. 194-206, 2014.

[46] S. B. Herner, F. A. Selmi, V. V. Varadan, and V. K. Varadan, "The effect of various dopants on the dielectric properties of barium strontium titanate," Materials Letters, vol. 15, no. 5-6, pp. 317324, 1993.
[47] X. Liang, Z. Meng, and W. Wu, "Effect of acceptor and donor dopants on the dielectric and tunable properties of barium strontium titanate," Journal of the American Ceramic Society, vol. 87, no. 12, pp. 2218-2222, 2004.

[48] A. K. Yadav, C. R. Gautam, and A. Mishra, "Mechanical and dielectric behaviors of perovskite $(\mathrm{Ba}, \mathrm{Sr}) \mathrm{TiO}_{3}$ borosilicate glass ceramics," Journal of Advanced Ceramics, vol. 3, no. 2, pp. 137146, 2014.

[49] A. K. Yadav and C. R. Gautam, "Dielectric behavior of perovskite glass ceramics," Journal of Materials Science: Materials in Electronics, vol. 25, no. 12, pp. 5165-5187, 2014. 

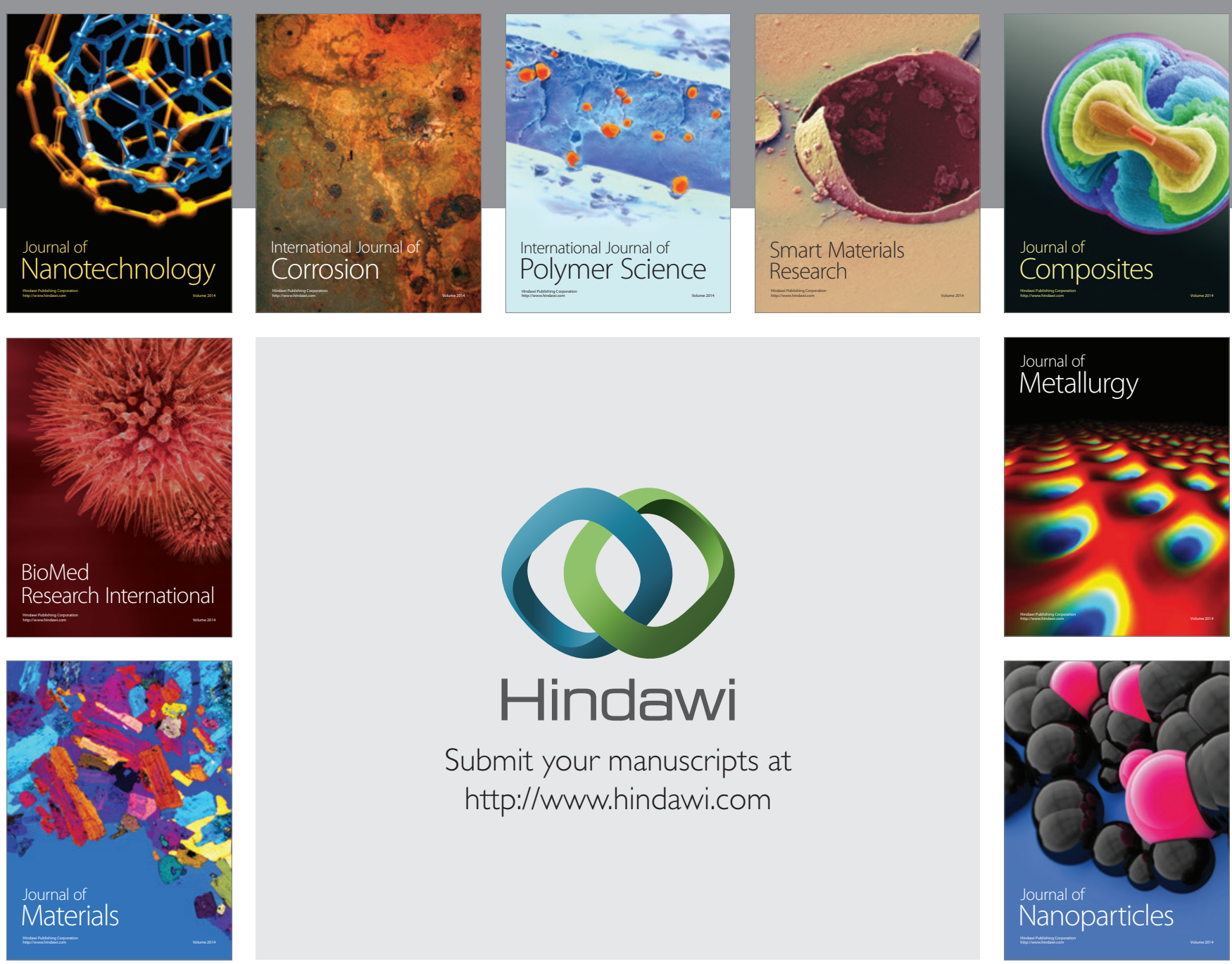

Submit your manuscripts at http://www.hindawi.com
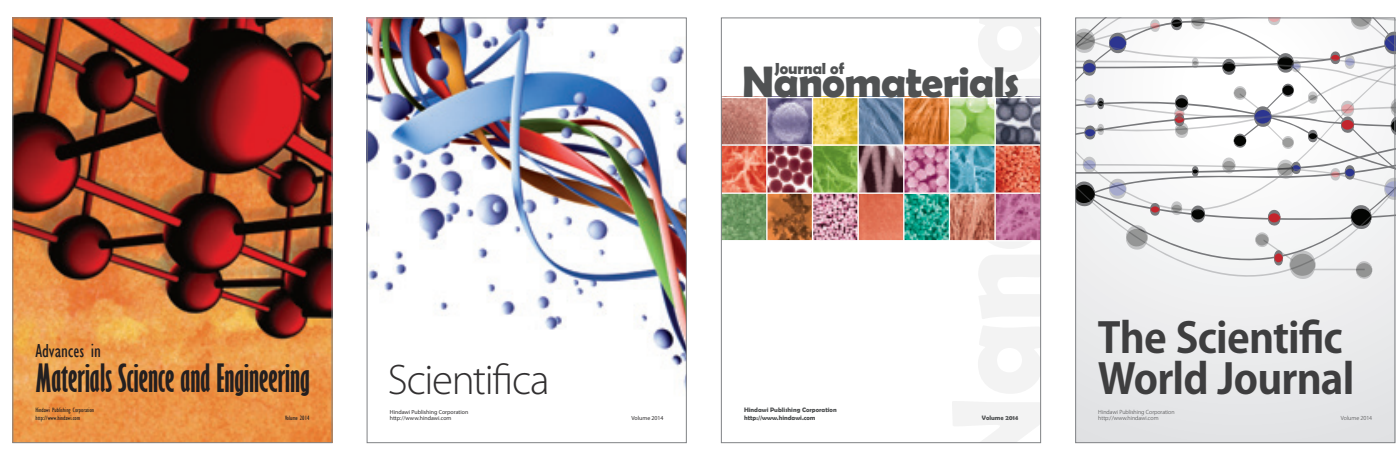

\section{The Scientific World Journal}
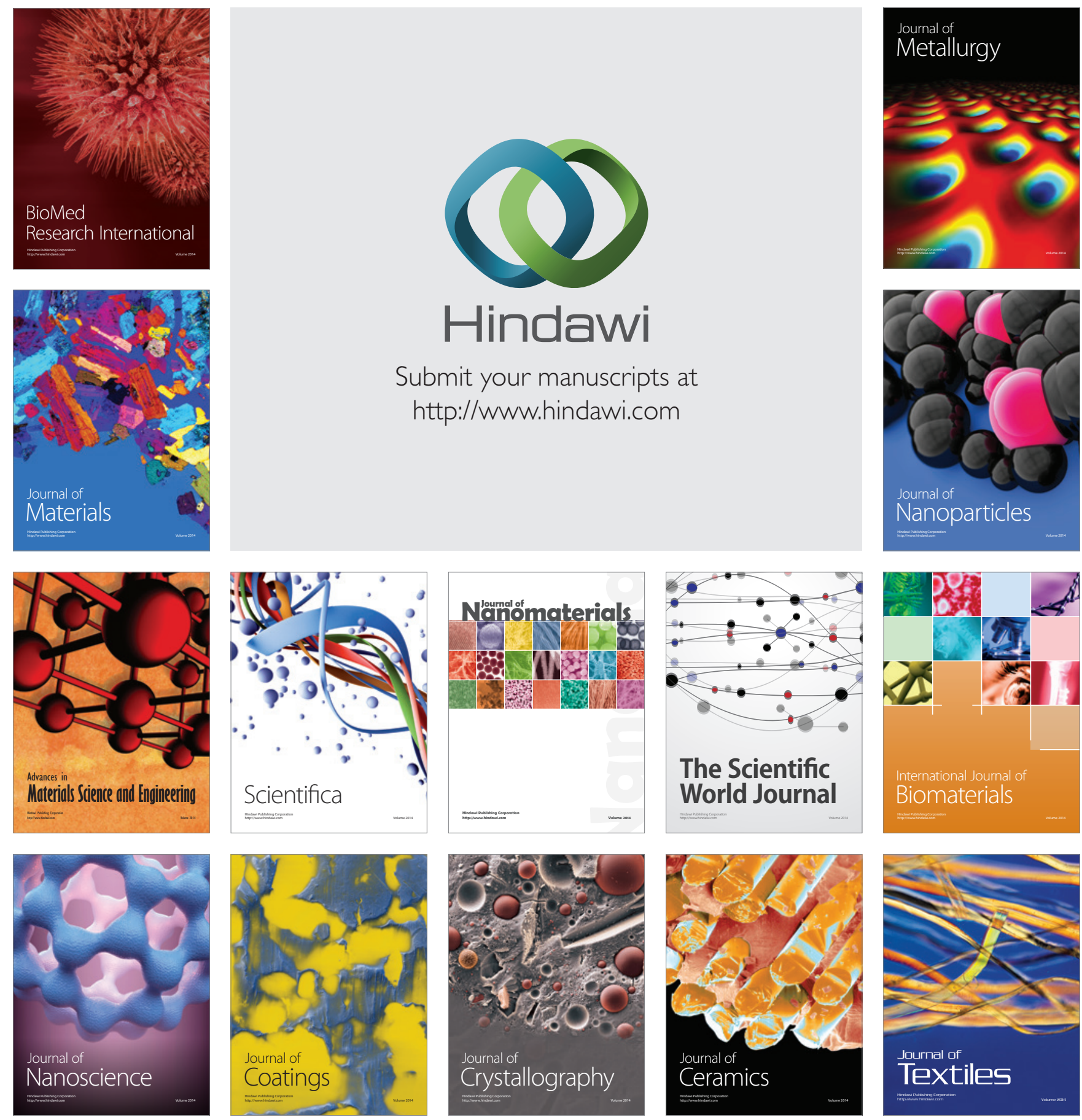